\title{
Bone regeneration in rabbit nasal bone by laser pulse shape control $\mathrm{CO}_{2}$ laser
}

\author{
Takayama $A^{1 *}$, Moroi $A^{1}$, Uno $K^{2}$, Saito $Y^{3}$, Yoshizawa $K^{1}$ and Ueki $K^{1}$ \\ ${ }^{1}$ Department of Oral and Maxillofacial Surgery, Division of Clinical Medicine, Graduate Faculty of Interdisciplinary Research, University of Yamanashi, Japan \\ ${ }^{2}$ Interdisciplinary Graduate School of Medicine and Engineering, University of Yamanashi, Japan \\ ${ }^{3}$ Fujiyoshida City Hospital, Dentistry and Oral Surgery, Yamanashi, Japan
}

\begin{abstract}
This study investigated the relationship between total short-pulse $\mathrm{CO}_{2}$ laser irradiation intensity and bone regeneration in rabbit nasal bone. Forty-eight rabbits (1216 weeks: $2.5-3.0 \mathrm{~kg}$ ) were used in this study. After the cranial bone was exposed under general anesthesia, $\mathrm{CO}_{2}$ laser irradiation was applied directly to the nasal bone under various conditions. Laser irradiation pulses with a spike pulse width of $360 \mathrm{~ns}$, a pulse tail length of $92.6 \mathrm{~ms}$, and an irradiation intensity per pulse of $650 \mathrm{~mJ} /$ $\mathrm{cm}^{2}$ were applied in a multipulse mode at a frequency of $50 \mathrm{~Hz}$. The rabbits were divided into four groups of six, in which a energy density of $88 \mathrm{~J} / \mathrm{cm}{ }^{2}$ (Group A), 220 $\mathrm{J} / \mathrm{cm}^{2}$ (Group B), $441 \mathrm{~J} / \mathrm{cm}^{2}$ (Group C), or $661 \mathrm{~J} / \mathrm{cm}^{2}$ (Group D) was applied. The rabbits were sacrificed 8 and 16 weeks after the procedure, and tissue sections were assessed histologically. Bone regeneration in the maxillary sinus was observed in groups $\mathrm{A}, \mathrm{B}$, and $\mathrm{C}$ at 8 and 16 weeks, but not in group D. The surface area ratio of new bone was significantly higher in group A. $88 \mathrm{~J} / \mathrm{cm}^{2}$ was the most effective energy density for bone regeneration.
\end{abstract}

Abbreviations: LLLT: Low-reactive level laser therapy; HLLT: High-level laser therapy; PDR: Photobiodestructive reaction; HE: Hematoxylin and eosin; PBS: Phosphate-buffered saline; BMP: Bone morphogenetic protein.

\section{Introduction}

Alveolar bone resorption following tooth loss occurs in horizontal and vertical directions from the alveolar crest [1]. Alveolar bone resorption is a major limiting factor in the use of dental implants. In particular, due to the proximity to the maxillary sinus, there may be insufficient alveolar bone for dental implants in the maxillary molar region. Thus, dental implant therapy is combined with bone regeneration to overcome bone deficiency in this region.

Sinus lifting is a safe and effective technique that is frequently used [2]. In sinus lifting, the maxillary sinus approach is indispensable. Vertical approach sinus regeneration reportedly is less invasive than the lateral window approach. However, even the vertical approach is invasive and limited in blind lifts, and is moreover associated with the risk of mucus rupture.

Grafts used for bone regeneration may be derived from autologous, allogeneic, xenogeneic, or synthetic materials [3-6]. However, collecting autologous bone graft involves a high level of invasiveness, bleeding, and risk of infection to the host site $[7,8]$. Synthetic materials are only osteoconductive, and not osteogenic or osteoinductive. Furthermore, synthetic materials can have impacts on ossein, depending on the resorption period.

Theodore et al. developed the ruby laser device, which uses a ruby crystal to emit laser, in 1960 [9]. Today, laser is widely used in medical and dental therapies. $\mathrm{CO}_{2}$ and Nd: YAG lasers are some of the types of lasers used in dentistry. These lasers operate in the visible or invisible infrared wavelength range $(380-10,600 \mathrm{~nm})$, which is non-ionizing. Lasers in the ultraviolet range have shorter wavelengths and higher frequencies, and thus may reach deep parts of tissues. As they may cause tissue destruction as well as DNA damage and protein and enzyme loss $[9,10]$, they are not applied in clinic.

Laser-induced bone therapy has been introduced as a method to promote neo-osteogenesis [11]. Clinical applications of laser irradiation fall into one of two categories: low-reactive level laser therapy (LLLT), which seeks to promote biological activity, and high-level laser therapy (HLLT), which is aimed at destroying living tissues. Some authors have reported that LLLT promotes bone regeneration in bone defects via activating processes at the cellular level [12-14]. HLLT has also been reported to promote bone healing without invasive $[11,15,16]$. However, HLLT produces a photobiodestructive reaction (PDR), i.e., thermal destruction of cells, and some reports are negative towards the use of HLLT on bone.

Uno et al. developed a novel laser device that controls pulse waveforms to reduce thermal tissue damage in HLLT. This type of laser reduces the number of irradiations by increasing the irradiation intensity per pulse, thereby preventing heat generation by laser irradiation. There was no reports on the use of $\mathrm{CO}_{2}$ laser to achieve bone regeneration

${ }^{*}$ Correspondence to: Akihiro Takayama DDS, Department of Oral and Maxillofacial Surgery, Division of Clinical Medicine, Graduate Faculty of Interdisciplinary Research, University of Yamanashi 1110 Shimokato, Chuo, Yamanashi 409-3898, Japan, Tel: +81-55-273-9673, Fax: +81-55-273-8210, E-mail: takayamaa@yamanashi.ac.jp

Key words: short-pulse $\mathrm{CO} 2$ laser, Bone regeneration, the nasal bone

Received: June 09, 2020; Accepted: July 13, 2020; Published: July 15, 2020 
without thermal damage in the maxillary sinus. Therefore, the present study aimed to investigate the relationship between short-pulse $\mathrm{CO}_{2}$ laser irradiation intensity and bone regeneration in domestic rabbit nasal bone.

\section{Materials and methods}

\section{Subjects}

The experimental protocol was approved by the Institutional Committee for Animal Care, University of Yamanashi, in accordance with the principles of the ARRIVE guidelines (A25-6).

\section{Experimental animals}

Forty-eight male Japanese white rabbits (12-16 weeks, $2.5-3.0 \mathrm{~kg}$ ) were used in this experiment. All animals were kept in a purposedesigned room for experimental animals and were fed a standard laboratory diet during the entire study period.

\section{Laser system}

In this experiment, a longitudinal excited $\mathrm{CO}_{2}$ laser that produces a short laser pulse with a circular beam (i.e. non-thermal damage) was used [17-19]. The laser pulse had a spike pulse width of $360 \mathrm{~ns}$, a pulse tail length of $92.6 \mu \mathrm{s}$, a spike pulse energy of $2.1 \mathrm{~mJ}$, and a total pulse energy of $57 \mathrm{~mJ}$.

The spot diameter was $4 \mathrm{~mm}$ on the target surface. Therefore, the fluence was $650 \mathrm{~mJ} / \mathrm{cm}^{2}$ in a single shot (Figure 1A,B).

\section{Surgical procedure}

The entire procedure was performed under sterile conditions. The animals were anesthetized with sodium pentobarbital $(25 \mathrm{mg} /$ $\mathrm{kg}$ ) administered intravenously. Then, the hair on the frontal bone was shaved, and $1.8 \mathrm{~mL}$ of $2 \%$ lidocaine containing 1:80,000 epinephrine was administered at the operating site. Both the frontal bone and nasoincisal suture lines were exposed by a perpendicular incision (Figure 2A,B).

Groups were divided as follows according to energy density (each group consisted of 12 rabbit.)

$$
\begin{aligned}
& \text { (A group;n=12) } 88 \mathrm{~J} / \mathrm{cm}^{2}, \\
& \left(\text { group;n=12) } 220 \mathrm{~J} / \mathrm{cm}^{2}\right. \text {, } \\
& \left(\text { group;n=12) } 441 \mathrm{~J} / \mathrm{cm}^{2},\right. \\
& \left(D \text { group;n=12) } 661 \mathrm{~J} / \mathrm{cm}^{2}\right.
\end{aligned}
$$

\section{histochemical examinations}

Rabbits were sacrificed 8 and 16 weeks postoperatively for histological assessment.

New bone formation was evaluated in an area demarcated by an arbitrarily selected $1-\mathrm{mm}$ segment within the irradiated zone and a parallel straight line $3 \mathrm{~mm}$ from it. The ratio of soft tissue was determined based on an area surrounding a 4-mm diameter of the irradiated zone and a parallel straight line drawn between the native bone $2 \mathrm{~mm}$ from it. The ratio of soft necrosis was determined based on an area surrounding the 4-mm diameter of the irradiated zone and a parallel straight line drawn between the native bone $1 \mathrm{~mm}$ from it (Figure 3A-C).

\section{Immunohistochemical examinations}

The specimens were fixed in $10 \%$ buffered formaldehyde overnight at $4^{\circ} \mathrm{C}$ and demineralized with $14 \%$ EDTA for 4 weeks. The specimens were dehydrated with a graded series of ethanol washes, cleared with
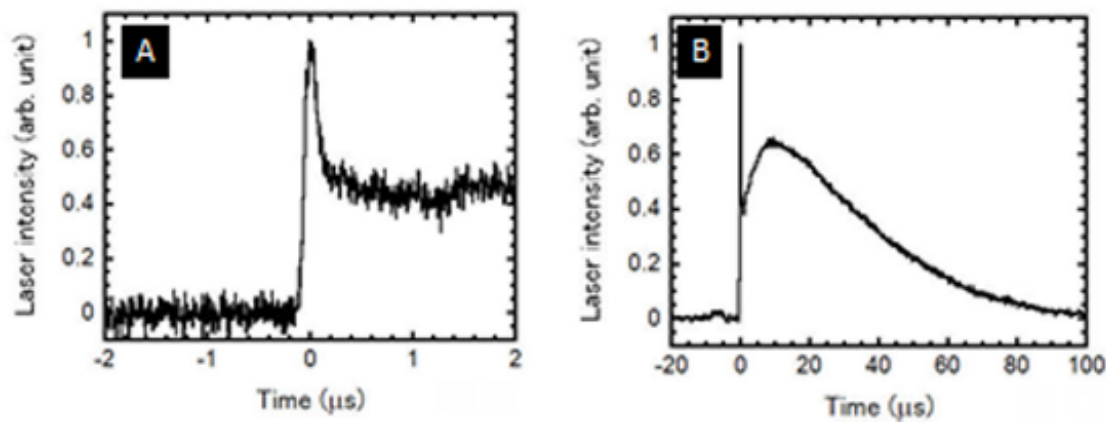

Figure 1. Overall laser pulse waveform (A). Magnified time-scale view of spike pulse (B)
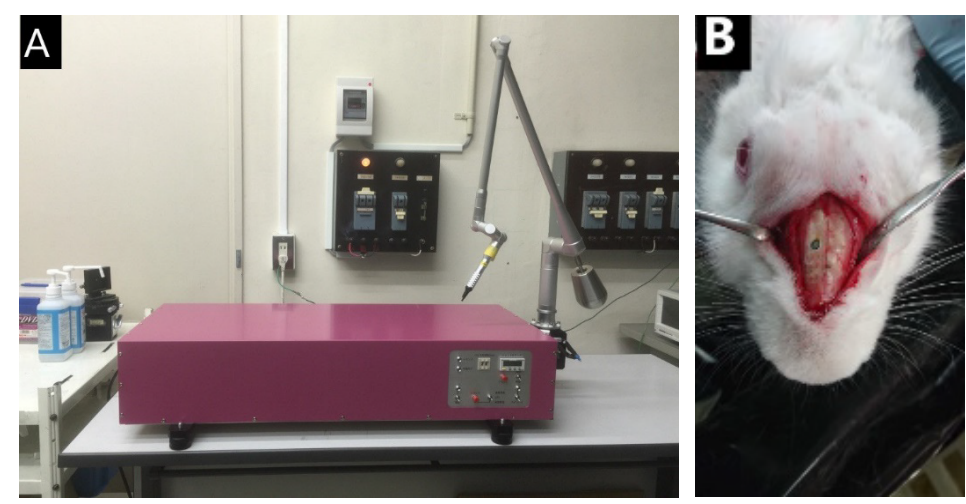

Figure 2. Intra-operative finding. Laser irradiator (A). Nasal bone after laser irradiation (B) 

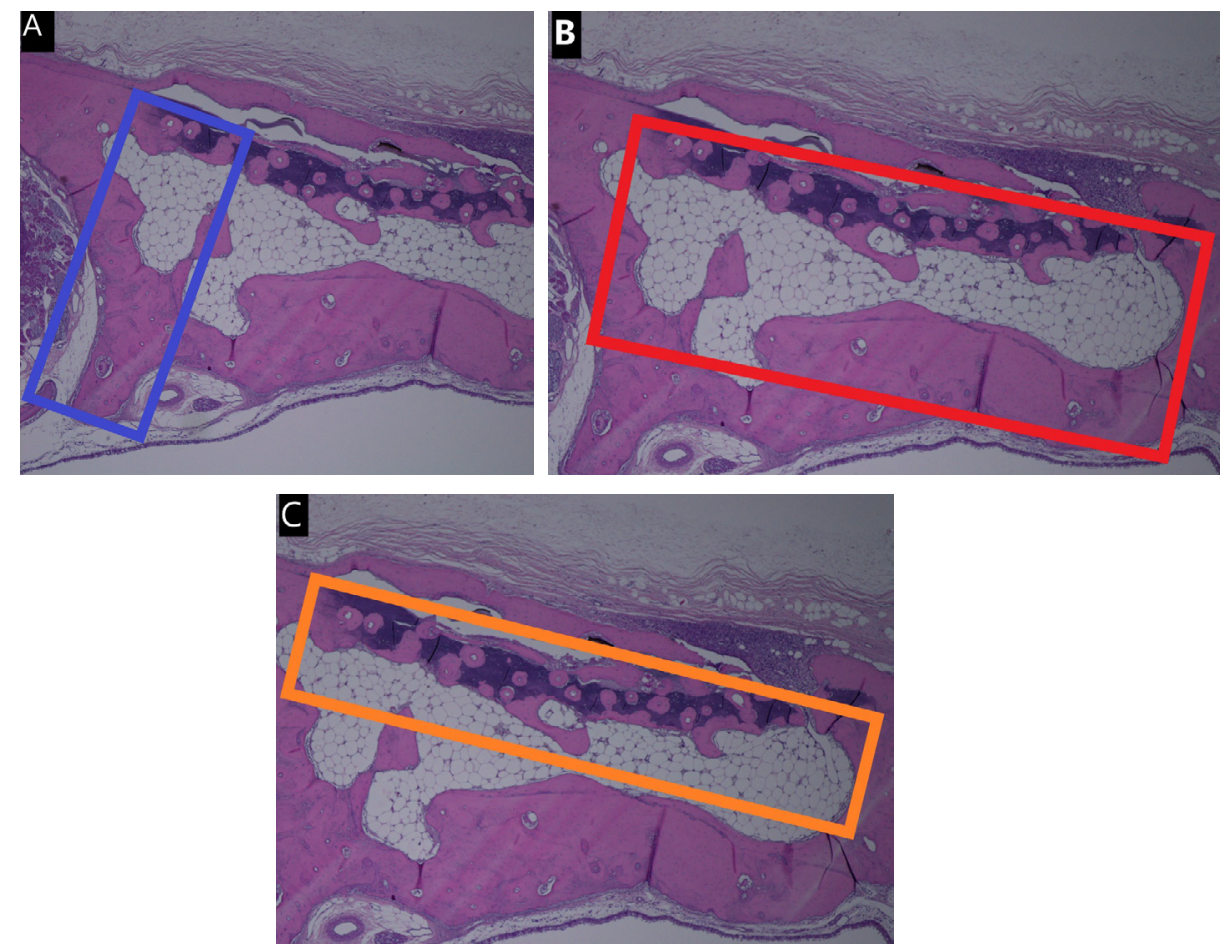

Figure 3. Description of the methods of histometric analysis. New bone formation was evaluated in an area demarcated by an arbitrarily selected 1-mm segment within the irradiated zone and a parallel straight line $3 \mathrm{~mm}$ from it (A). The ratio of soft tissue was determined based on an area surrounding a 4-mm diameter of the irradiated zone and a parallel straight line drawn between the native bone $2 \mathrm{~mm}$ from it (B). The ratio of soft necrosis was determined based on an area surrounding the 4-mm diameter of the irradiated zone and a parallel straight line drawn between the native bone $1 \mathrm{~mm}$ from it $(\mathrm{C})$

xylene, and embedded in paraffin. Multiple 5- $\mu$ m-thick sections were cut parallel to the coronal plane of the head at the center region and mounted on gelatin-coated glass slides. First, the prepared sections were stained with hematoxylin and eosin (HE).

The new bone area ratio and bone defect ratio was measured with animaging software program (Image J; the Research Services Branch, National Institute of Mental Health, Bethesda, ML, USA). The measurement was performed five times by an author (A.T.) to confirm the reproducibility of the scores, and the mean value was used as the result.

Then, they were treated successively with $0.3 \%$ Tween 20 (Tokyo chemical industry Co., Ltd., Tokyo, Japan) in phosphate-buffered saline (PBS) for 1 hour for cell permeabilization, followed by $0.3 \%$ hydrogen peroxide in methanol for 10 minutes to inhibit intrinsic peroxide activity. They were then incubated overnight at room temperature with antibody bone morphogenetic Japan, Tokyo, Japan) at 1:300 dilution for 1 hour, and $0.01 \%$ diaminobenzidine tetrahydrochloride in the presence of $0.02 \%$ hydrogen peroxide in $50 \mathrm{mM}$ Tris-HCL ( $\mathrm{pH}$ 7.5) for 10 minutes. The sections counterstained with hematoxylin were observed under Olympus BX 50 microscope (Olympus; Tokyo, Japan). They were then dehydrated in alcohol and mounted for light microscopy to count the number of positively stained active cells in the regeneration site. The area of observation was determined to be an arbitrary point in the region where the new bone ratio was measured. The number of BMP-2-stained cells per 1000 voluntary cells in this area was counted manually using a high magnification photomicrograph $(\times 200)$ (Fig. 4). The measurements were performed 5 times by an author (A.T.) to confirm the reproducibility of the scores; the mean value was used as the result.

\section{Statistical analyses}

SPSS v. 25 (IBM, USA) was used for statistical analysis. Inter-group differences were assessed by one-way analysis of variance and changes over time were assessed by repeated-measures ANOVA. Differences were considered significant at $\mathrm{P}<0.05$.

\section{Results}

No deaths or signs of infection were observed in any of the animals during the experimental period.

\section{Histological examinations}

In group $\mathrm{A}$, immature bone and limited osteoblastoma were observed in week 8. Mature bone tissue was observed more abundantly than in the other groups. Small quantities of inflammatory cells and carbonized tissues were observed, but adipose tissue was less abundant than in the other groups. Mature bone tissue was observed on week 16.

In group $\mathrm{B}$, immature bone and limited osteoblastoma were observed in week 8 , and mature bone tissue was also observed. Adipose tissues were found under carbonized tissue. Mature bone tissue was observed in week 16, but adipose tissue was less abundant than in week 8. In group C, immature bone and limited osteoblastoma were observed in week 8 .

Mature bone tissue was observed on the side of the nasal cavity. More adipose tissue was found under the carbonized tissue than in groups A and B. Limited mature bone and adipose tissues were observed in week 16 .

In group $\mathrm{D}$, a small quantity of immature bone was observed in week 8. Adipose tissue was observed more abundantly under the 
carbonized tissue than in other groups. Mature bone was nearly absent, due to the heat. Limited mature bone and fat tissues were observed in the fat layer in week 16 (Figures 5A-D and 6A-D).

\section{Statistical examination}

The percentage of new bone ratio: There were significant differences in changes in the ratio of new bone surface area over time between the different groups (between subjects: $\mathrm{F}=734.647, \mathrm{df}=3 \mathrm{P}<$ 0.001; within subjects: $\mathrm{F}=52.556, \mathrm{df}=1 \mathrm{P}<0.001$, repeated-measures ANOVA) (Figure 7).
In group $\mathrm{C}$, there were no significant differences between weeks 8 and 16. On week 8 , animals in group A exhibited more new bone generation than those in the other three groups. Newly formed bone was observed in groups B, C, and D albeit in greater quantities in groups $\mathrm{B}$ and $\mathrm{C}$ than in group $\mathrm{D}$.

Ratio of necrotic tissue: There were significant differences in changes in the ratio of necrotic tissue over time (between subjects: $\mathrm{F}=$ 498.938, $\mathrm{df}=3 \mathrm{P}<0.001$; within subjects: $\mathrm{F}=73.918, \mathrm{df}=1 \mathrm{P}<0.001$, repeated-measures ANOVA) (Figure 8).

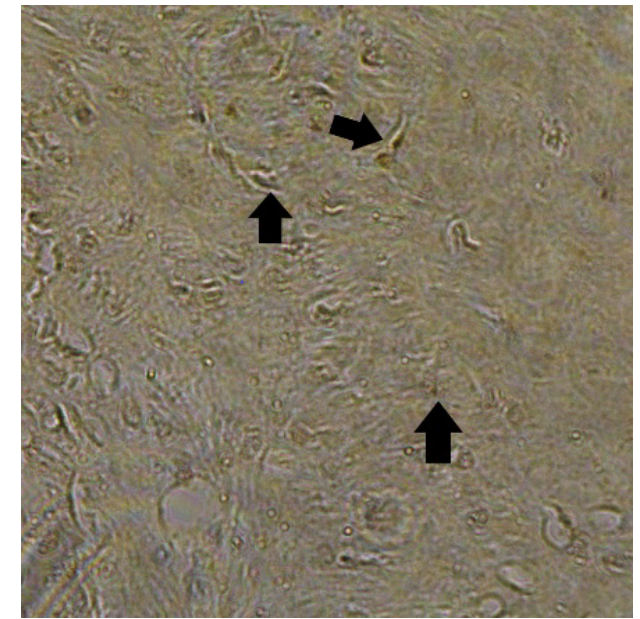

Figure 4. Black arrows showing BMP-2-stained cells $(\times 200)$
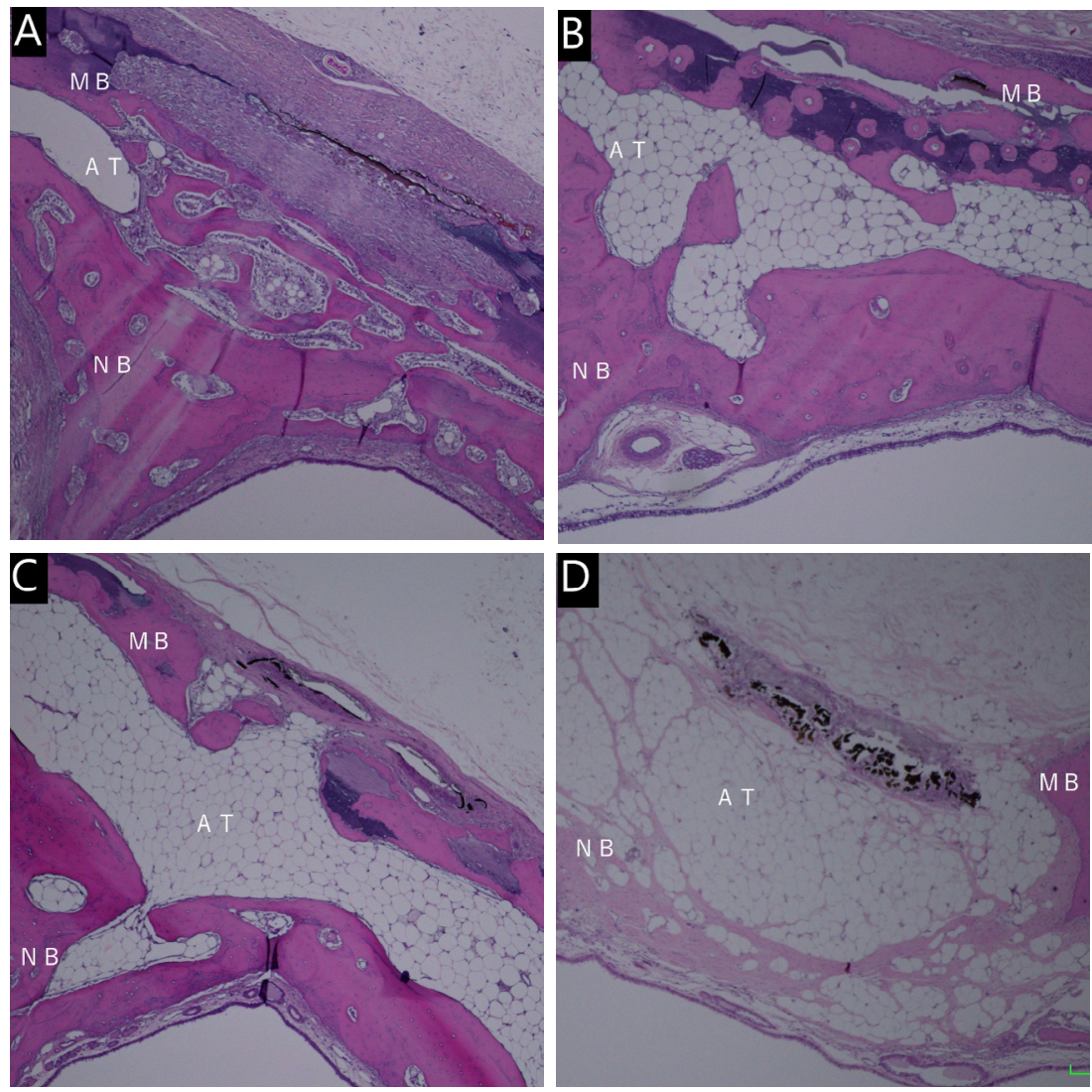

Figure 5. Micrograph 8 weeks after irradiation. Energy density of $88 \mathrm{~J} / \mathrm{cm}^{2}(A)$. Energy density of $220 \mathrm{~J} / \mathrm{cm}^{2}(B)$. Energy density of $441 \mathrm{~J} / \mathrm{cm}^{2}(C)$. Energy density of $61 \mathrm{~J} / \mathrm{cm}^{2}(D)$. Hematoxylin-eosin staining, original magnification $\times 40$, MB: mother bone, NB: new bone. AT: Adipose tissue 

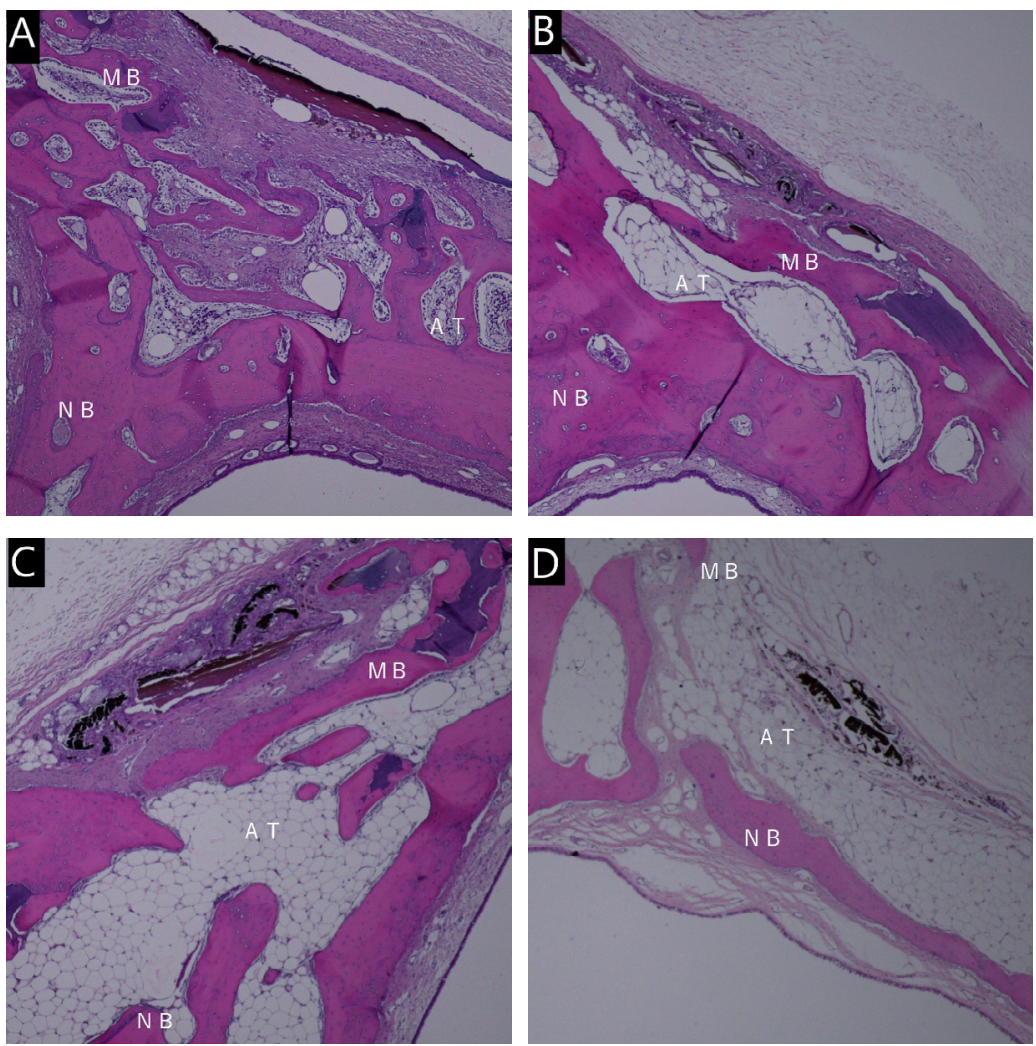

Figure 6. Micrograph 16 weeks after irradiation. Energy density of $88 \mathrm{~J} / \mathrm{cm} 2$ (A). Energy density of $220 \mathrm{~J} / \mathrm{cm} 2(\mathrm{~B})$. Energy density of $441 \mathrm{~J} / \mathrm{cm} 2(\mathrm{C})$. Energy density of $61 \mathrm{~J} / \mathrm{cm} 2(\mathrm{D})$. Hematoxylin-eosin staining, original magnification $\times 40$, MB: mother bone, NB: new bone. AT: Adipose tissue

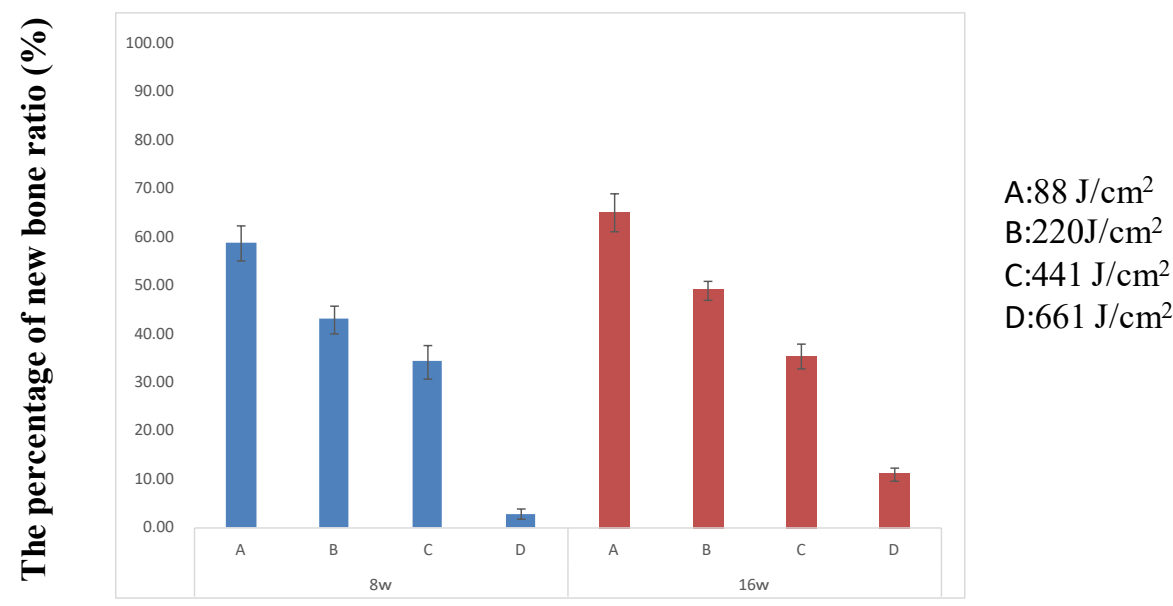

Figure 7. There were significant differences in changes in the ratio of new bone surface area over time between the different groups. Differences were considered significant at $\mathrm{P}<0.05$

However, there were no significant differences between weeks 8 and 16 in all groups. Carbonized tissue was more abundant in group A, than in groups $\mathrm{B}, \mathrm{C}$, and $\mathrm{D}$ at both 8 and 16 weeks.

Ratio of soft tissue: There were significant differences in changes in the ratio of soft tissue over time (between subjects: $\mathrm{F}=0.147, \mathrm{df}=3 \mathrm{P}$ $=0.93$; within subjects: $\mathrm{F}=9415.7, \mathrm{df}=1 \mathrm{P}<0.001$, repeated-measures ANOVA) (Figure 9).
In week 8, more dense bone tissue had formed in group A than in the other three groups. Adipose tissue was more abundant in group $\mathrm{D}$ than in groups $\mathrm{A}, \mathrm{B}$ and $\mathrm{C}$.

Ratio of BMP-2-Stained Cells: There were no significant differences in changes in the ratio of BMP-2-stained cells over time (between subjects: $\mathrm{F}=1.157, \mathrm{df}=3 \mathrm{P}=0.351$; within subjects: $\mathrm{F}=3.065, \mathrm{df}=1 \mathrm{P}$ $=0.095$, repeated-measures ANOVA) (Figure 10). 


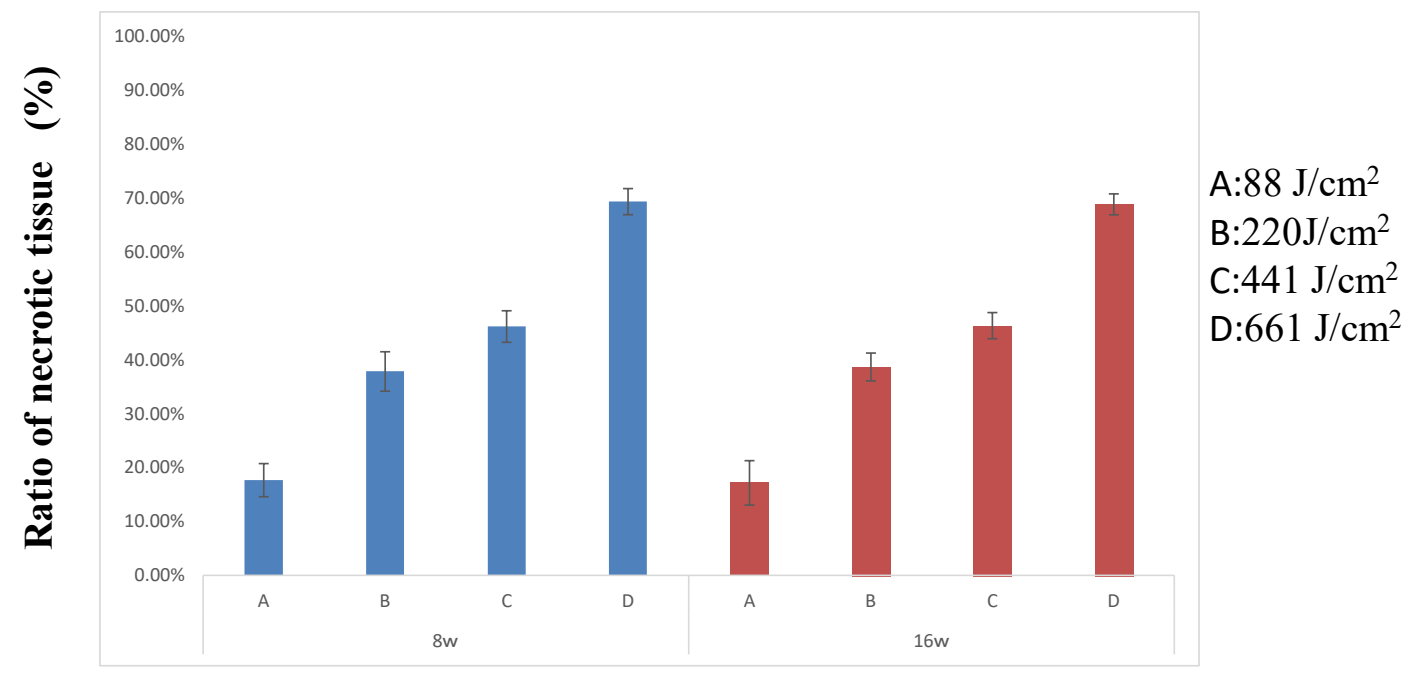

Figure 8. There were significant differences in changes in the ratio of necrotic tissue over time. Differences were considered significant at $\mathrm{P}<0.05$

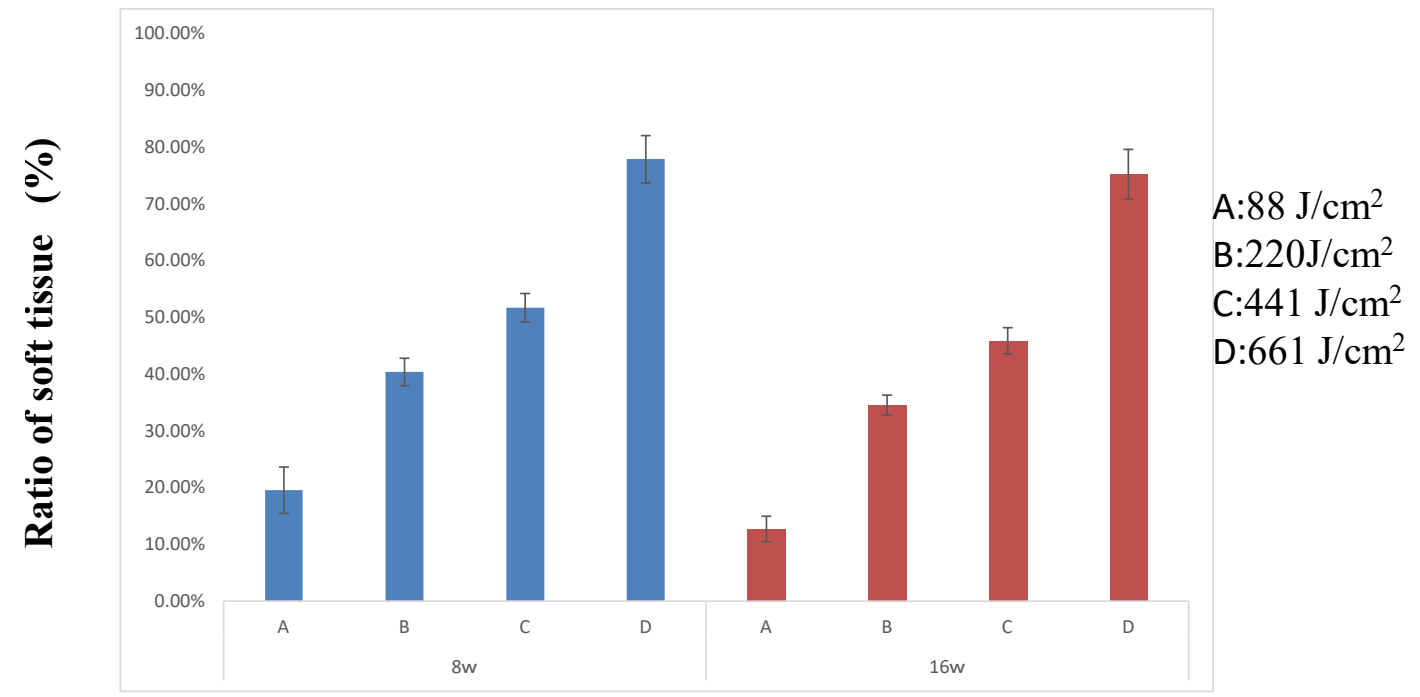

Figure 9. There were significant differences in changes in the ratio of soft tissue over time. Differences were considered significant at $\mathrm{P}<0.05$

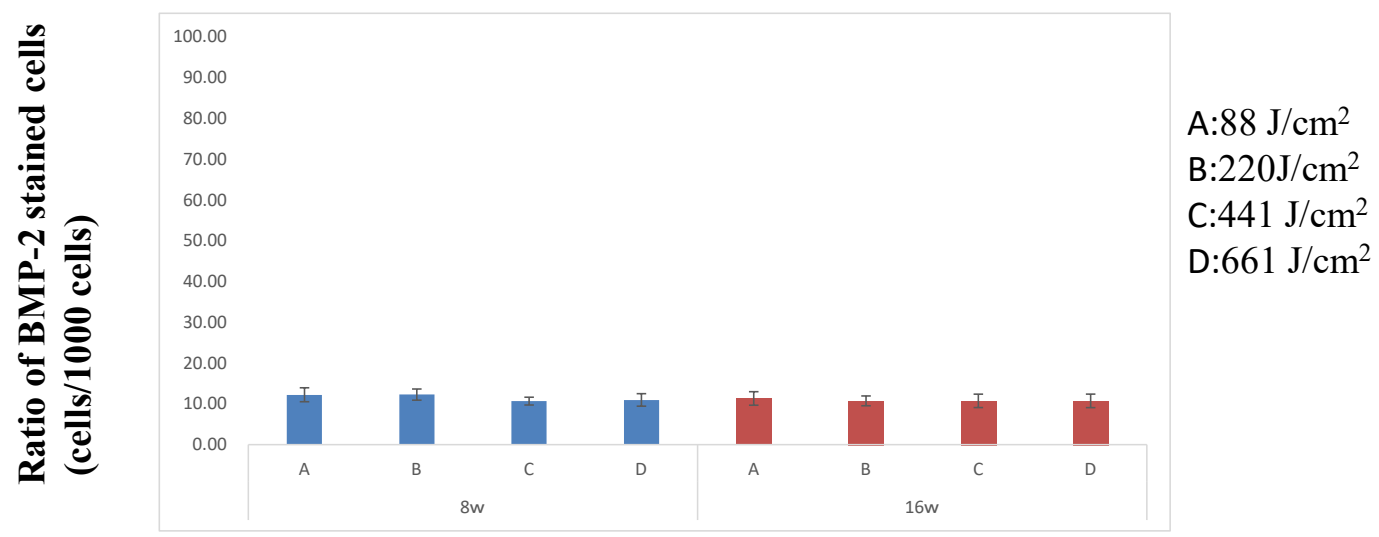

Figure 10. There were no significant differences in changes in the ratio of BMP-2-stained cells over time. Differences were considered significant at $\mathrm{P}<0.05$ 
There were no significant differences between groups A, B, C and D on week 8 or 16 .

\section{Discussion}

Although studies have reported that laser therapy stimulates tissues and promotes tissue repair [20-22], the detailed mechanisms of tissue repair have remained unknown. Several methods in which an adequate stimulus is applied to tissues to promote tissue repair have been reported, including ozone therapy and low-intensity pulsed ultrasound [23-26]. It has been suggested that the efficacy of laser irradiation for tissue stimulation depends not only on the total irradiated dose, but also on the irradiation time and conditions [21].

LLLT reportedly has anti-inflammatory and analgesic effects, and helps wound healing $[27,28]$. The mechanisms underlying the bone formation-promoting effects of LLLT at the cellular level are largely unknown. Yokose et al. reported that stimulation of bone cells that function to recognize force in bone tissue with laser or ultrasound suppressed the mRNA expression of SOST, encoding sclerostin, which is secreted from bone cells, and enhanced that of Dmp-1, the protein product of which has pro-osteogenic action [29]. However, negative effects on bone healing have also been reported [30]. LLLT requires numerous cycles of irradiation until bone formation is induced, because of the very low per pulse irradiation intensity.

$\mathrm{CO}_{2}$ laser therapy is classified as HLLT and is clinically used for mucosal incision and hemostasis by induced the PDR. Recently, $\mathrm{CO}_{2}$ laser therapy has been reported as a potential treatment to promote new bone generation [31]. In terms of the mechanism of new bone formation, it has been suggested that laser stimulation of mesenchymal cells promotes their differentiation in early stages to promote new bone regeneration ${ }^{46}$. However, such enhancing effects of HLLT on bone healing have not been validated in basic experiments. $\mathrm{A} \mathrm{CO}_{2}$ laser operates in the wavelength range of 9.2-11.4 $\mu \mathrm{m}$, which falls within the absorbance spectrum for calcium hydroxyapatite $(9.0-11.0 \mu \mathrm{m})$ [32]. This material has a high affinity to water and teeth, and therefore is used in dentistry [33,34]. However, continuous-wave and long-pulse irradiation causes tissue carbonization, therefore its use on hard tissues such as bones and teeth has been limited [33,34]. Therefore, Uno et al. developed a small and simple short-pulse $\mathrm{CO}_{2}$ laser and successfully cut teeth without carbonization [35]. $\mathrm{CO}_{2}$ laser-induced bone formation in the neck, ilium, and femur in rats has been recently reported [36-38]. However, $\mathrm{CO}_{2}$ laser irradiation causes damage to the cortical bone, inflammatory response, and marrow degeneration, due to the heat generated, especially in the case of continuous-wave or long-pulse laser irradiation $[38,39]$. Naka et al. reported the effectiveness of HLLT for femoral bone regeneration [11]. However, while bone apposition was observed, so was carbonization and bone resorption of the bone tissue surrounding the irradiated area. They stated that additional studies were needed to find the optimal irradiation energy density to minimize thermal damage of the cortical bone and inflammatory response of the marrow. Carbonate generated by HLLT-produced heat may have a negative effect on bone regeneration [38,39], and it was suggested that improving the carbonizing effects of $\mathrm{CO}_{2}$ laser will enable revealing the detailed osteogenic effects of HLLT. Therefore, a longitudinally excited $\mathrm{CO}_{2}$ laser with a long optical cavity developed by Uno et al. was used to investigate the effects of HLLT on bone regeneration. In the longitudinal excitation method, the laser light is emitted in the same direction as the longitudinal discharge. The discharge tube of a longitudinal excitation $\mathrm{CO}_{2}$ laser is composed of a dielectric tube with electrodes attached to its two ends. In a longitudinal excitation $\mathrm{CO}_{2}$ laser, the laser pulse waveform is largely dependent on the gas and excitation circuit by the low gas pressure discharge with a long discharge length. This has made it possible to use a short-pulsed laser with and without pulse tail and long pulses on one device, simply by adjusting the medium gas [40]. Suppression of the heating effect can be expected because it is lowfluence compared to long-pulse $\mathrm{CO}_{2}$ laser [40]. In the present study, heat-induced bone resorption was not observed on the irradiated side at $88.5 \mathrm{~J} / \mathrm{cm}^{2}, 220 \mathrm{~J} / \mathrm{cm}^{2}$, or $440 \mathrm{~J} / \mathrm{cm}^{2}$, while bone regeneration was observed in the maxillary sinus. Thus, short-pulse $\mathrm{CO}_{2}$ laser irradiation seems to have the same effect as a sinus lift. Furthermore, there were differences in bone regeneration and carbonization, depending on the total fluence. However, thermal damage, inflammatory response, and marrow degeneration were observed at an excessively high energy of $661 \mathrm{~J} / \mathrm{cm}^{2}$, which induced osteonecrosis, and only slight bone regeneration in week 8 .

Several osteogenic markers affect bone remodeling. BMP-2 is expressed in the early stage of bone remodeling and modulates the expression of RANKL and CSF-1, which is understood to be the mechanism of bone formation promotion [40-46]. Mesenchymal progenitor cells involved in osteogenesis are present in the mucosal lining of the maxillary sinuses. An in-vitro study reported that increased expression of BMP-2, BMP-4, and BMP-7 was associated with enhanced osteogenesis, and maximum BMP-2 expression was observed in week $2[46,47]$. However, we observed the bone in its mature stage; thus, the effects of the laser could not be observed directly. We did not observe significant differences in the numbers of BMP-2-positive cells between weeks 8 and 16, indicating that significant bone regeneration occurs earlier. However, increased BMP-2 expression was found in group $\mathrm{D}$, which suggests that a secondary remodeling occurred in the bone marrow side, including osteonecrotic, adipose, and fibrous tissues. At $88 \mathrm{~J} / \mathrm{cm}^{2}$, there were no intermediary tissues between the native and new bone, whereas at $661 \mathrm{~J} / \mathrm{cm}^{2}$, we observed intermediary soft tissue. Based on this observation, we suggest that two mechanisms were at work: laser-induced bone tissue regeneration mediated by and unrelated to osteonecrosis.

LLLT irradiation on the mucosa must be repeated numerous times because the energy is low. Unlike LLLT applied via the mucosa, $\mathrm{CO}_{2}$ laser irradiation in the present study was applied directly to the bone surface by dissecting the mucoperiosteal flap. Therefore, such $\mathrm{CO}_{2}$ laser treatment may promote bone regeneration in single doses and is thus believed to be clinically extremely effective.

This study had some limitations. While four laser intensities were applied and tested in the present study, the optimal laser irradiation conditions remain unknown. Further investigations that focus on the fundamental biological mechanisms, including growth factors and hormones that induce bone regeneration and numerous signaling molecules involved in bone metabolism, are needed to determine optimal $\mathrm{CO}_{2}$ irradiation conditions. Further, it remains to be investigated whether $\mathrm{CO}_{2}$ laser irradiation promotes bone regeneration via the same mechanisms as DMP and sclerostin.

In conclusion, this study demonstrated the bone augmentationpromoting effects of $\mathrm{CO}_{2}$ laser in the maxillary sinus; however, it remains unknown whether the ossein can withstand implant embedding. $\mathrm{CO}_{2}$ laser irradiation directly on the bone surface in sinus lifting can be an extremely effective treatment to stimulate bone regeneration in the maxillary sinus.

\section{Acknowledgements}

This study was not funded by any specific project or grant. 


\section{Conflicts of interest}

The authors declare no conflicts of interest.

\section{References}

1. Schropp L, Wenzel A, Kostopoulos L (2003) Bone healing and soft tissue contour changes following single-tooth extraction: A clinical and radiographic 12-month prospective study. Int J Periodontics Restorative Dent 23: 313-323. [Crossref]

2. Froum SJ, Wallace S, Cho SC (2013) Histomorphometric comparison of different concentrations of recombinant human bone morphogenetic protein with allogeneic bone compared to the use of $100 \%$ mineralized cancellous bone allograft in maxillary sinus grafting. Int J Periodontics Restorative Dent 33: 721-730. [Crossref]

3. Wetzel AC, Stich H, Caffesse RG (1995) Bone apposition onto oral implants in the sinus area filled with different grafting materials. A histological study in beagle dogs. Clin Oral Implants Res 6: 155-163. [Crossref]

4. Haas R, Donath K, Födinger M (1998) Bovine hydroxyapatite for maxillary sinus grafting: comparative histomorphometric fi ndings in sheep. Clin Oral Implants Res 9: $107-116$.

5. Rosenberg E, Rose LF (1998) Biologic and clinical considerations for autografts and allografts in periodontal regeneration therapy. Dent Clin North Am 42: 467-490. [Crossref]

6. Bauer TW, Muschler GF. Bone graft materials (2000) An overview of the basic science. Clin Orthop Relat Res 371: 10-27.

7. Simion M, Baldoni M, Rossi P (1994) A comparative study of the effectiveness of e-PTFE membranes with and without early exposure during the healing period. Int $J$ Periodontics Restorative Dent 14: 166-180.

8. Moreno Vazquez JC, Gonzalez de Rivera AS, Gil HS (2014) Complication rate in 200 consecutive sinus lift procedures: Guidelines for prevention and treatment. J Oral Maxillofac Surg 72: 892-901.

9. A.R. Eriksson T, Albrektsson B, Grane (1982) Thermal injury to bone. Int J Oral Surg 11:115

10. A.R. Eriksson T, Albrektsson (1983) Temperature threshold levels for heat-induced bone tissue injury: A vital microscopic study in the rabbit. J Prosthet Dent 50: 101. [Crossref]

11. Naka T, Yokose S (2012) Application of Laser-Induced Bone Therapy by Carbon Dioxide Laser Irradiation in Implant Therapy. Int J Dent 40: 94-96. [Crossref]

12. D. Gigo-Benato, S. Geuna, S. Rochkind (2005) Phototherapy for enhancing peripheral nerve repair: a review of the literature. Muscle Nerve 31: 694-701.

13. C.C. Alcântara, D. Gigo-Benato, T.F. Salvini, A.L.R. Oliveira, J.J. Anders, T.L Russo (2013) Effect of low-level laser therapy (LLLT) on acute neural recovery and inflammation-related gene expression after crush injury in rat sciatic nerve. Lasers Surg Med 45: 246-252.

14. Jéssica BG, Daniela VB, Cleuber RB (2016) Effects of low-level laser therapy on autogenous bone graft stabilized with a new heterologous fibrin sealant. Journal of Photochemistry \& Photobiology, B: Biology 162: 663-668.

15. Frentzen M, Götz W, Ivanenko M (2003) Osteotomy with 80- $\mu$ s CO2 laser pulseshistological results. Lasers Med Sci 18(2): 119-124.

16. Nakamura Y, Hossain M, Watanabe H (1999) A study on the morphological changes of the rat mandibular bone with TEA CO2 laser. J Clin Laser Med Surg 17(5): 211-215.

17. Uno K, Hayashi H, Akitsu T, Jitsuno T (2014) Longitudinally excited CO2 Laser with short laser pulse for hard tissue drilling. Proc SPIE Int Soc Opt Eng 18; 8929: 89290L.

18. Uno K, Dobashi K, Akitsu T (2013) Relation between Discharge Length and Laser Pulse Characteristics in Longitudinally Excited CO2 Laser. J Infrared Milli Terahz Waves 34: 225-230.

19. Uno K, Hayashi H, Akitsu T (2013) Discharge Circuit for Longitudinally Excited CO2 Laser. J Infrared Milli Terahz Waves 34: 217-224.

20. Chang WD, Wu JH, Wang HJ, Jiang JA (2014) Therapeutic outcomes of low-level laser therapy for closed bone fracture in the human wrist and hand. Photomed Laser Surg 32: $212-218$.

21. Mayer L, Gomes FV, Carlsson L, Gerhardt-Oliveira M (2015) Histologic and resonance frequency analysis of per-implant bone healing after low-level laser therapy: An In vivo study. Int J Oral Maxillofac Implants 30: 1028- 1035.
22. Pereira CL, Sallum EA, Nociti FH, Jr., Moreira RW (2009) The effect of low-intensity laser therapy on bone healing around titanium implants: A histometric study in rabbits. Int J Oral Maxillofac Implants 24: 47-51. [Crossref]

23. Pinheiro AL, Gerbi ME (2006) Photoengineering of bone repair processes. Photomed Laser Surg 24(2): 169-178. [Crossref]

24. Bronoosh P, Tanideh N, Noorafshan A (2015) Effects of low-intensity pulsed ultrasound on healing of mandibular bone defects: an experimental study in rabbits. Int J Oral Maxillofac Surg 44(2): 277-284.

25. Acar AH, Yolcu Ü, Altındis, S (2016) Bone regeneration by low-level laser therapy and low intensity pulsed ultrasound therapy in the rabbit calvarium. Arch Oral Biol 61: 60-65. [Crossref]

26. Ahmet Hüseyin Acar, Ümit Yolcu, Sedat Altındiș , Mehmet Gül , Hilal Alan, Sıddık Malkoç (2016) Bone Regeneration by Low-Level Laser Therapy and Low-Intensity Pulsed Ultrasound Therapy in the Rabbit Calvarium. Arch Oral Biol 61: 60-65. [Crossref]

27. Kemmotsu O, Sato K, Furomido H, Harada K, Takigawa C, Kaseno S (1991) Efficacy of low reactive-level laser therapy for pain attenuation of postherpetic neuralgia. Laser Ther 3: 71-75.

28. Enwemeka CS, Parker JC, Dowdy DS, Harkness EE, Sanford LE, Woodruff LD (2004) The efficacy of low power lasers in tissue repair and pain control, a meta analysis study. Photomed Laser Surg 22: 323-329. [Crossref]

29. Yokose S, Kadokura H (2013) Low-power carbon dioxide laser irradiation reduces sclerostin expression, but stimulates Dmp-1 expresstion in osteocyte-like cells of rats. J Bio-Integ 3: 53-60.

30. R. David, M. Nissan, I. Cohen, M. Soudry (1996) Effect of low-power He-Ne laser on fracture healing in rats. Lasers Surg Med 19: 458-464. [Crossref]

31. Cho TJ, Gerstenfeld LC, Einhorn TA (2002) Differential temporal expression of members of the transforming growth factor beta superfamily during murine fracture healing. J Bone Miner Res 17: 513-520. [Crossref]

32. Nelson DG, Shariati M, Glena R (1986) Effect of pulsed low energy infrared laser irradiation on artificial caries-like lesion formation. Caries Res 20(4): 289-299. [Crossref]

33. K.H Chan, J. M. Jew, D. Fried (2016) Proc. of SPIE 9692-969206.

34. W.S.Gora, A.McDonald, D.P.Hamd,J.D (2016) Shephard,proc. of SPIE 9692-969205.

35. Uno K, Yamamoto T, Akitsu T, Jitsuno T (2017) Dental hard tissue drilling by longitudinally excited $\mathrm{CO} 2$ laser. Medical Laser Applications and Laser-Tissue Interactions VIII 104170.

36. Krause LS, Cobb CM, Rapley JW (1997) Laser irradiation of bone? An in vitro study concerning the effects of the $\mathrm{CO} 2$ laser on oral mucosa and subjacent bone. $J$ Periodontol 68(9): 872-880. [Crossref]

37. McDavid VG, Cobb CM, Rapley JW (2001) Laser irradation of bone-III. Long-term healing following treatment by $\mathrm{CO} 2$ and Nd:YAG lasers. J Periodontol 72(2): 174-182.

38. Friesen LR, Cobb CM, Rapley JW (1999) Laser irradiation of bone-II. Healing response following treatment by $\mathrm{CO} 2$ and Nd:YAG Lasers. J Periodontol 70(1): 75-83.

39. McKee MD (1993) Effects of CO2 laser irradiation in vivo on rat alveolar bone and incisor enamel, dentin, and pulp. J Dent Res 72(10): 1406-1417.

40. Uno K, Nakamura K, Goto T (2009) Longitudinally Excited CO2 Laser with Short Laser Pulse like TEA CO2 Laser. J Infrared Milli Terahz Waves 30: 1123-1130.

41. Mandal C. C, Ghosh Choudhury G., and Ghosh-Choudhury N (2009) Phosphatidylinositol 3 kinase/Akt signal relay cooperates with Smad in bone morphogenetic protein-2-induced colony stimulating factor-1 (CSF-1) expression and osteoclast differentiation. Endocrinology 150: 4989-4998. [Crossref]

42. Manolagas S. C, and Jilka R. L (1995) Bone marrow, cytokines, and bone remodeling Emerging insights into the pathophysiology of osteoporosis. New Engl J Med 332: 305-311. [Crossref]

43. Olsen B. R., Reginato A. M., Wang W (2000) Bone development. Annu Rev Cell Dev Biol 16: 191-220. 
44. Ghosh-Choudhury N, Singha P. K, Woodruff K, St Clair P, Bsoul S, Werner S. L, Choudhury G. G (2006) Concerted action of Smad and CREB-binding protein regulates bone morphogenetic protein-2-stimulated osteoblastic colony-stimulating factor-1 expression. J Biol Chem 281: 20160-20170. [Crossref]

45. Itoh K, Udagawa N, Katagiri T, Iemura S, Ueno N, et al. (2001) Bone morphogenetic protein 2 stimulates osteoclast differentiation and survival supported by receptor activator of nuclear factor- $\mathrm{kB}$ ligand. Endocrinology 142: 3656-3662. [Crossref]
46. Abe E, Yamamoto M, Taguchi Y, Lecka-Czernik B, O'Brien C. A, et al. (2000) Essential requirement of BMPs-2/4 for both osteoblast and osteoclast formation in murine bone marrow cultures from adult mice: antagonism by noggin. J Bone Miner Res 15: 663673.

47. Gruber R, Kandler B, Fuerst G (2004) Porcine sinus mucosa holds cells that respond to bone morphogenetic protein (BMP)-6 and BMP-7 with increased osteogenic differentiation in vitro. Clin Oral Implants Res 15: 575-580.

Copyright: $(\mathbb{C} 2020$ Takayama A. This is an open-access article distributed under the terms of the Creative Commons Attribution License, which permits unrestricted use, distribution, and reproduction in any medium, provided the original author and source are credited. 